\title{
EFFECTS OF GENETICALLY MODIFIED APROTININ-EXPRESSING TOBACCO ON THREE EARTHWORM SPECIES
}

\author{
W.B. STILWELL ${ }^{1}$, M. O'CALLAGHAN ${ }^{1}$, E.P.J. BURGESS ${ }^{2}$ \\ and E.I. BARRACLOUGH ${ }^{2}$ \\ ${ }^{1}$ AgResearch, PO Box 60, Lincoln, New Zealand \\ ${ }^{2}$ HortResearch, Private Bag 92169, Auckland, New Zealand \\ Corresponding author: maureen.ocallaghan@agresearch.co.nz
}

\begin{abstract}
Genetically modified (GM) plants expressing protease inhibitors (PIs), such as aprotinin, are protected from attack by a range of pest insects. Aprotinin binds to the digestive trypsin of insects feeding on the plants, reducing their growth and survival. The potential non-target effects of GM aprotinin-expressing tobacco plants on growth and survival of three earthworm species were examined in replicated pot experiments. At weekly intervals for eight weeks, earthworms were provided with either GM aprotininexpressing tobacco (approx. $0.1 \%$ of total leaf protein) or unmodified control leaves. Survival of earthworms was unaffected by leaf type in both experiments. Growth of Lumbricus rubellus did not differ between GM and control treatments. Aporrectodea caliginosa did not grow under the assay conditions, with earthworms fed on control leaves showing greater weight losses than those fed on GM leaves. In contrast, Eisenia fetida fed on control leaves gained significantly more weight than those fed on GM leaves but when this assay was repeated, there was no significant difference between the two leaf types. Experiments are ongoing but results to date suggest that at realistic field rates there is little impact of aprotinin-expressing tobacco on the three earthworm species tested.
\end{abstract}

\section{LIGHT OR GRAVITY: WHAT DRIVES FIRST INSTAR CLOVER ROOT WEEVIL LARVAE TO ENTER THE SOIL?}

\author{
D.L. HACKELL \\ AgResearch, Ruakura Research Centre, Private Bag 3123, Hamilton. \\ Corresponding author:deborah.hackell@agresearch.co.nz
}

Clover root weevil (Sitona lepidus) is a pest of white clover largely throughout the North Island of New Zealand. Larval feeding occurs on the plant's roots, significantly reducing clover persistence in pastures and impairing its ability to fix atmospheric nitrogen. Adults lay their eggs above ground where they hatch. Newly hatched first instar larvae then bury themselves into the soil and locate the clover nodules. Knowledge of abiotic factors, such as light and gravity, that assist in nodule location contributes to understanding this pest's ecology as well as being helpful in establishing robust assay techniques. To determine the importance of light and gravity on first instar larval behaviour two separate $24 \mathrm{~h}$ Petri dish assays were conducted. Results of the first choice assay showed first instars exhibited a significant $(\mathrm{P}=0.001)$ photo negative response and greater searching distances on the dark side of the Petri dish compared with the light side. However, when no choice was given between lighting regimes, larvae showed no overall difference $(\mathrm{P}=0.907)$ in their searching distances. The second assay found first instar clover root weevil larvae moved randomly under vertical conditions and did not show evidence of geotaxis in either light or dark conditions. 